\title{
Genetic and environmental factors in the etiology of schizophrenia - towards mainstreaming
}

\author{
Czynniki genetyczne i środowiskowe \\ w etiologii schizofrenii - w stronę podejścia integracyjnego
}

\section{Agnieszka Łaba-Stefanek ${ }^{1}{ }_{\mathrm{BDEF}}$, Ewelina Dziwota ${ }^{2}{ }_{\mathrm{ABDEF}}$, Marcin Olajossy ${ }^{2}{ }_{\mathrm{DE}}$}

1. Medical Students' Association, Medical University of Lublin

2. II Department of Psychiatry and Psychiatric Rehabilitation, Medical University of Lublin

\begin{abstract}
The prevalence of schizophrenia in a population is about $1 \%$. Many efforts are constantly made to find the cause of this mental illness. Authors of this article provide groups of factors influencing the development of the disease. Among these factors, genetics seems to be an interesting and reasonable trend of exploration. GWAS research studies allow not only determining the point mutations in the genome, but also try to give an answer to the question about the biological mechanisms of disease. A microRNA MIR137, which is involved in neurogenesis and maturation of neurons may be an example. However, the genetic component may not always be sufficient to trigger symptoms. Definitely, a large group of environmental factors has an important role. Schizophrenia is a complex disease in which many genes interact with the environment. This article is a presentation of genes and the impact of various external environmental factors, leading to the onset of schizophrenia. Interrelationship between polygenic determinant of disease and the impact of both environmental and social factors in future will certainly become the field of interest for research concerning the etiology and course of schizophrenia-spectrum disorders.
\end{abstract}

Keywords: schizophrenia, behavioral genetics, genome

\section{Streszczenie}

Częstość występowania schizofrenii w populacji wynosi 1\%. Stale podejmowane są starania, by odnaleźć przyczynę tej choroby psychicznej. Możemy podać grupy czynników mających wpływ na rozwój choroby. Wśród nich genetyka wydaje się być ciekawym i zasadnym kierunkiem poszukiwań. Badania GWAS pozwalają nie tylko określić punktowe mutacje w genomie, ale także próbują dać odpowiedź na pytanie o biologiczne mechanizmy choroby. Przykładem może być mikroRNA MIR137, które bierze udział w neurogenezie i dojrzewaniu neuronów. Jednak komponenta genetyczna nie zawsze może być wystarczająca, by zapoczątkować wystąpienie objawów. Zdecydowanie znaczącą rolę odgrywa duża grupa czynników środowiskowych. Schizofrenia to złożone schorzenie, w którym wiele genów wchodzi w interakcje ze środowiskiem. Niniejszy artykuł jest prezentacją oddziaływania genów oraz różnorodnych czynników zewnętrznych, środowiskowych, prowadzącego do ujawnienia się schizofrenii. Wzajemne powiązania między poligenowym uwarunkowaniem choroby a wpływem czynników środowiskowych i społecznych za pewne będą w przyszłości wdzięcznym polem do badań nad etiologią i przebiegiem chorób z grupy schizofrenii.

Słowa kluczowe: schizofrenia, genetyka behawioralna, genom

\section{Introduction}

The prevalence of schizophrenia equals about $1 \%$ of general population. Major efforts are constantly being made to find the cause of this mental illness. There are certain groups of factors influencing the development of the disease. Among them, genetics seems to be a reasonable direction of exploration. However, the genetic component may not always be sufficient to trigger symptoms. A substantial group of environmental factors definitely plays a major role in this process. Schizophrenia is a complex disease in which interaction between numerous genes and the environment occurs.
The intensive studies on human genome sequencing conducted as a part of Human Genome Project since 1990 and successfully finished in 2003 , have resulted in a notable increase in research projects on the etiology of various illnesses. In the psychiatric field, attempts have been made to link human personality traits and behavior with potential genetic predispositions [1]. The so-called "behavioral genetics" has developed. Searching the genetic susceptibility in plentiful psychiatric disorders and human behavior has become the mainstream approach - it even triggered some talks about "the third wave of biological psychiatry". This led to greater expectations from the 
scientist on one side, and patients and their families on the other. They anticipated that explaining the genetic aspect of the etiology of particular diseases and disturbed behavior would enable genetic manipulations and bring therapeutic effects. Opinions have emerged, according to which investigating the genetic level will explain the origin of higher emotions, define the core of human identity. The concept, that from the evolutionary standpoint we are a mere packaging for genes, has become popular. Certainly, genetic reductionism and determinism lead to fatalism, eliminate human experience, the role of thinking, action and moral decisions. Acknowledging over time that "one gene - one disease" theory is illegitimate - terms such as genetic link, susceptibility or incidence risk were introduced [1].

Observations of familial schizophrenia incidence show that there exists a genetic susceptibility to this disease. The incidence risk in monozygotic twin, whose brother or sister is affected by the disease, is between $41 \%$ and $65 \%$. The risk rate for children whose both parents suffer from schizophrenia equals 28\% [2]. The risk rate is also increased if the disease affects further relatives (5\%). In addition, the possibility of disease occurrence is higher for persons whose relative suffers from bipolar affective disorder [3].

The possibilities offered by molecular biology significantly enhance search for the etiology of schizophrenia. Linkage studies, determining susceptibility of certain genes to be inherited together, are among most fundamental methods. This test allows stating the chromosomal location of the gene and the inheritance pattern of particular traits. The use of linkage studies has indicated multiple genes involved in schizophrenia, i.e. NRG1, DTNBP1, NCAM1 OR DISC1 and ANKK1 genes. In the course of investigation, DISC1 gene appeared to be linked to not only schizophrenia, but also major depression and bipolar disease. It encodes a protein responsible for development of the nervous system by proliferation, differentiation and migration [4]. Alike, ANKK1 protein takes part in cell differentiation and proliferation, however, it is found only in astroglia - the source of neural progenitor cells of the brain cortex. The Taq1A polymorphism, analyzed not only in terms of schizophrenia, but also alcoholism, nicotinism and drug addiction, is located on the same gene. Both Dubertret and Parsons have confirmed in their studies, that this particular polymorphism occurs more often in schizophrenic patients and that it is inherited by diseased children from their parents [5]. It is the polymorphism that the schizophrenia phenotype, as well as the age at onset depend on [5].

In psychiatry, the GWAS studies (genome-wide association studies) which facilitate genotyping of hundreds of thousands of SNPs (single nucleotide polymorphism) proved to be very fruitful. SNPs are single point mutations present in the whole genome that can be detected by analyzing their hybridization with oligonucleotides [6].

GWAS is the objective means of the whole genome variability assessment, allowing for identification of specific loci of the genetic risk for complex genetic disorders. There are several study models within GWAS. Totaled genotyping of a number of DNA probes brings numerous benefits, yet decreases chances to identify rare alleles. It has been replaced with single DNA probe genotyping with additional analytical possibilities concerning haplotypes, epistasis and aforementioned CNVs [7].

Until the end of 2011, there had been published nearly 20 GWAS association studies on schizophrenia. Three research teams: International Schizophrenia Consortium (ISC), Molecular Genetics of Schizophrenia (MGS) and SGENE demonstrated significant genetic alterations in MHC (major histocompatibility complex) regions, TCF4 (transcription factor 4 involved in development of the nervous system), NRGN (neurogranine) [8]. In 2011, investigators Ripke S, Sanders AR, Kendler KS announced five new loci discovered in GWAS: 1p23.3 (MIR137), 2q32.3 (PCGEM1), 8p23.2 (CSMD1), 8q21.3 (MMP16), 10q24.32-q24.33 (CNNM2/NT5C2). In the same year, loci characteristic for citizens of the Eastern countries (11p11.2, 8p12, 1q24.2) were identified [12].

The GWAS studies allow identifying not only point mutations in genome, but also attempt to provide an answer to the question about biological mechanisms of the disease. MicroRNA MIR137, which takes part in neurogenesis and neuronal maturation, may serve as an example. [8]. According to researchers, microRNA may be of colossal importance for coordination of the extensive protein system. This concerns microRNA regulating B1 GABA receptor in particular. The GABBR1 gene is located among major histocompatibility complex genes and has been recently proved to undergo the most substantial methylation. It is crucial for creation of signal pathways in schizophrenia. According to GWAS studies, the MHC region where GABBR1 is placed, contains the greatest number of SNPs [11].

$\mathrm{CNV}$ - copy number variation of DNA fragments is a chromosome structural abnormality; at times even several genes may undergo duplication or deletion. Studies have shown that microdeletions, which disturb genes responsible for neurodevelopmental processes and synaptic plasticity, are more prevalent in schizophrenia [7]. Various CNVs linked with schizophrenia have been investigated since 2008. It seems that among most important findings, there are loci: 1q21.1, 2p16.3, 3q29, 15q11.2, 15q13.3, 16p13.1, 22q11.2 [9]. Out of these, 3q29 microdeletion appears to be crucial [10]. Deletions 
demonstrate greater penetration, as well as CNVs in comparison with duplications. A considerable number of CNVs is hereditary, nonetheless novel mutations are also of particular importance in schizophrenia. For example, they are responsible for incidence of schizophrenia only in one of monozygotic twins [9]. Both English and American researchers had investigated 662 triplets proband - parents and stated that de novo mutations were significantly more frequent than in the control group (5.1\% vs. $2.2 \%$ ). Eight of the newly created CNVs were localized in aforementioned loci: 3q29, 15q11.2, 15q13.3, 16p11.2. There was also noted the emergence of CNV bound up with disorders other than schizophrenia i.e. deletion in 1q21.1 region (TAR - thrombocytopenia - absent radius syndrome) or duplication in 7q11.23 region (WilliamsBeuren Syndrome) [13].

Researchers decided to investigate the role of de novo mutations in schizophrenia, determine protein products of mutated genes and their role in brain during human development. Their findings have confirmed that fetal prefrontal cortex disorders lie at the bottom of schizophrenia process. The prefrontal cortex has extensive connections with other cortical regions, basal ganglia and limbic system. This emphasizes the importance of both coordinated development and spatial regulation in creating integrated system of neural pathways. De novo mutated genes' expression is as well visible in different brain regions, such as frontal and temporal lobes, hippocampus, amygdala, thalamus. ITGA3, LAMA2 genes have a major role in neural migration, SLIT2 and SLIT3 in axonal transmission. CELSR2 takes part in signal transduction and cell adhesion, whereas ADCY9, CACNA1I, GLS, SLC18A2 are responsible for neurotransmitter signaling, along with synaptic transmission. It is the CACNA1I gene that codes for a T-type brain-specific calcium channel antagonized by clozapine, among others. The CELSR2, HIVEP1, ITGA3, SERPINI1, SLIT2 gene expression profiles were different in neurons derived from stem cells of schizophrenic people, than in those from the control group. The possibility of polygenetic interactions is suggested by the fact that nine out of the investigated patients had mutations in more than a single gene [14].

The second influential group of ethiological factors is constituted by environmental components determining the occurrence of schizophrenia in genetically predisposed people. During recent years, schizophrenia has started to be perceived through the lens of neurodevelopmental hypothesis, according to which unfavorable factors provoke anomalous brain development in perinatal stage. Stress is the common denominator for numerous environmental factors. Among the biological consequences of stress, there are hypothalamic-pituitary-adrenal glands axis dysregulation and increase in dopamine re- lease in striatum. In addition, hippocampal volume is lowered due to neural degeneration, synaptic plasticity in prefrontal cortex is reduced as well [15].

The neurodevelopmental theory is reflected in the studies concerning the influence of maternal stress on the condition of the fetus. The stress resulting from difficult life experiences, i.e. war, grief, unintended pregnancy is particularly harmful for the baby during $1^{\text {st }}$ and $3^{\text {rd }}$ trimester, when brain development is the most susceptible to injuries. Additionally, it exerts the aforementioned dysregulation of hypothalamic-pituitary-adrenal glands axis and negative influence on placenta. Fetus subjected to stress has greater risk of developing schizophrenia, depression and anxiety disorders. The critical lesions are localized in hippocampus and amygdala, where increased steroid and CRH receptor expression occurs. Dysfunction of these regions resulting from prenatal stress, leads to cognitive deficits, operational and spatial memory and new object recognition disorders, as has been proved on animal models [15].

Stress is not the unique proven risk factor for schizophrenia during fetal and perinatal period. Hypoxia, preterm labor, infections, bleeding, gestational diabetes and serologic conflict are also confirmed risk factors [16]. The forenamed infections are primarily caused by influenza, measles, rubella, VZV, polio and herpes viruses, as well as Toxoplasma gondii. Other sources indicate consecutive obstetric complications as schizophrenia risk factors. These are preeclampsia, uterine atony, sudden cesarean section and fetal abnormalities - microcephaly, low birth weight, inborn malformations [15].

One of the circumstances associated with stress is emigration. Many emigrants are socially discriminated, encounter social exclusion, which may contribute to psychiatric disorders. However, the lack of adaptation of emigrants' immunological system to local neutropic viruses and parasites has been discussed over the years. Higher incidence of schizophrenia refers to the first and second generation of emigrants, as well as the minority groups. It has been suggested, that schizophrenia might be overdiagnosed in emigrants due to confusing disease symptoms with language difficulties $[15,16]$.

Residing in regions with high urbanization rates is a very important aspect remaining to discuss. It is connected with greater activity of amygdala and frontal gyrus cortex [15]. The risk of the disease is 1.5 times higher in residents of large cities. According to Pedersen and Mortensen, living in urban agglomerations is the most harmful for youths under the age of $15[15,16]$.

Head trauma is often experienced by people with cognitive function impairments $[15,16]$. However, on the other hand, head trauma causing cerebral injury may be the cause of disease development [16]. Mild head injuries 
in childhood decrease the age of onset of first symptoms in people with strong genetic predisposition. Psychosis is experienced about 5 years earlier in this group. Despite this fact, the majority of head traumas have no health consequences [17].

Cannabinols are investigated with respect to their potential therapeutic influence in schizophrenia. Nonetheless, many analyses show that they are significant risk factor for the disease. Primarily, the use of THC (delta-9tetrahydrocannabinol) by adolescents may lead to onset of schizophrenia symptoms in early adulthood. These observations are applicable to adolescents with family history of the disease or exposed to domestic violence, in particular $[18,19]$. The effects of cannabinols certainly depend on dosage time and frequency, as well as dose. Cognitive deficits may be compensated as a result of abstinence. However, other impairments (attention, working memory, executive functions) remain long-term in individuals who started smoking marijuana under the age of 15 . Such early THC use disturbs the endocannabinoid system, thus impeding final brain maturation [20].

\section{Summary}

This article presents the review of exclusive, significant etiological factors for schizophrenia. Despite constant development of psychiatry, the disorder still remains a riddle in some aspects. Nevertheless, both genetic and environmental factors undoubtedly influence disease occurrence.

The interconnections between polygenetic determinant of the disease and the influence of both environmental and social factors will certainly become the field of interest for studies concerning the etiology and course of schizophrenia-spectrum disorders.

\section{Wstęp}

Częstość występowania schizofrenii $\mathrm{w}$ populacji wynosi $1 \%$. Stale podejmowane są starania, by odnaleźć przyczynę tej choroby psychicznej. Możemy podać grupy czynników mających wpływ na rozwój choroby. Wśród nich genetyka wydaje się być ciekawym, a zarazem zasadnym kierunkiem poszukiwań. Jednak komponenta genetyczna nie zawsze może być wystarczająca, by zapoczątkować wystąpienie objawów. Zdecydowanie znaczącą rolę odgrywa duża grupa czynników środowiskowych. Schizofrenia to złożone schorzenie, w którym wiele genów wchodzi w interakcje ze środowiskiem.

Badania nad sekwencją ludzkiego genomu prowadzone intensywnie od 1990 r. w ramach Human Genome Project, uwieńczone sukcesem w 2003 r. doprowadziły do znacznego wzrostu badań nad pochodzeniem wielu chorób, a w dziedzinie psychiatrii także do prób łączenia ludzkich cech, sposobów zachowania z uwarunkowaniami genetycznymi [1]. Rozwinęła się tzw. „genetyka behawioralna". Poszukiwanie uwarunkowań genetycznych wielu chorób psychicznych i ludzkiego zachowania stały się wiodącym podejściem badawczym - zaczęto wręcz mówić o „trzeciej fali biologicznej psychiatrii”. Doprowadziło to do wzrostu oczekiwań z jednej strony naukowców, z drugiej strony pacjentów i ich rodzin, że wytłumaczenie podstaw genetycznych powstawania chorób i zaburzonych zachowań do prowadzi do możliwości oddziaływania na genom i do efektów leczniczych. Pojawiły się poglądy, że zejście do poziomu genów wyjaśni pochodzenie uczuć wyższych, określi istotę człowieczeństwa. Określenie, że z punktu widzenia ewolucji jesteśmy tylko opakowaniem dla genów stało się popularne. Niewątpliwie genetyczny redukcjonizm i determinizm prowadzi do fatalizmu, eliminuje ludzkie doświadczenie, rolę myśli, działań i wyborów moralnych. Z czasem uznając, że podejście do zaburzeń psychicznych na zasadzie „jeden gen, jedna choroba" jest niezasadne - wprowadzono określenia takie jak powiązania genetyczne, podatność czy ryzyko wystąpienia choroby[1].

Obserwacje nad rodzinnym występowaniem schizofrenii pokazują, że istnieje genetyczna skłonność do tej choroby. U bliźniaka monozygotycznego, którego brat lub siostra choruje, ryzyko zachorowania wynosi od $41 \%$ do $65 \%$. Dla dzieci obojga chorych rodziców prawdopodobieństwo to równa się 28\%. [2] Ryzyko zachorowania zwiększają także dalsi krewni obciążeni schizofrenią (5\%). Co więcej możliwość ujawnienia się choroby wzrasta również u osób mających wśród krewnych cierpiącego na chorobę afektywną dwubiegunową. [3]

Możliwości biologii molekularnej istotnie wspomagają poszukiwania początków schizofrenii. Jednym z podstawowych badań jest analiza sprzężeń, czyli test pokazujący skłonność poszczególnych genów do wspólnego dziedziczenia. Pozwala ona określić pozycję genów na chromosomie i sposób dziedziczenia danej cechy. Wykorzystanie analizy sprzężeń ukazało wiele genów związanych ze schizofrenią. Są to np.: gen NRG1, DTNBP1, NCAM1 czy geny DISC1 i ANKK1. Gen DISC1 w toku badań okazał się być związany nie tylko ze schizofrenią, ale także z ciężką depresją i chorobą dwubiegunową. Koduje on białko odpowiedzialne za rozwój układu nerwowego poprzez proliferację, różnicowanie i migrację. [4] Podobnie białko ANKK1 odpowiada za różnicowanie i proliferację komórek, ale znajduje się ono tylko w astrogleju - stąd pochodzą neuronalne komórki progenitorowe kory mózgu . Na tym genie znajduje się polimorfizm Taq1A, badany nie tylko pod kątem schizofrenii, ale także alkoholizmu, 
nikotynizmu i narkomanii. Zarówno Dubertret, jak i Parsons potwierdzili w swoich badaniach, iż polimorfizm ten częściej występuje u chorych na schizofrenię, a także chore dzieci dziedziczą go po swoich rodzicach. To od niego zależny jest fenotyp schizofrenii, a także wiek zachorowania. [5]

Bardzo owocne w psychiatrii okazały się być badania asocjacyjne całego genomu GWAS (genome-wide association studies), które umożliwiają genotypowanie setek tysięcy SNP (single nucleotyde polymorphism). SNP to pojedyncze punktowe mutacje występujące w całym genomie, wykrywane poprzez analizę ich hybrydyzacji z oligonukleotydami. [6]

GWAS daje obiektywną ocenę zmienności w całym genomie, identyfikując konkretne loci ryzyka genetycznego dla złożonych zaburzeń genetycznych. W ramach GWAS istnieje kilka modeli badawczych. Zsumowane genotypowanie wielu próbek DNA daje wiele korzyści, ale obniża szanse do wykrycia rzadkich alleli. Jego miejsce zajęło genotypowanie pojedynczych próbek DNA z dodatkowymi możliwościami analitycznymi dotyczącymi haplotypów, epistazy, ale także wspomnianych już CNV. [7]

Do końca 2011 roku zostało opublikowanych około prawie 20 badań asocjacyjnych schizofrenii GWAS. Trzy zespoły badawcze: International Schizophrenia Consortium (ISC), Molecular Genetics of Schizophrenia (MGS) oraz SGENE wykazały istotne zmiany genetyczne $\mathrm{w}$ obszarach MHC (kompleks główny układ zgodności tkankowej), TCF4 (czynnik transkrypcyjny 4 biorący udział w rozwoju układu nerwowego), NRGN (neurogranina). [8] W 2011 roku badacze Ripke S, Sanders AR, Kendler KS zgłosiło pięć nowych loci znalezionych w badaniu GWAS: 1p23.3 (MIR137), 2q32.3 (PCGEM1), 8p23.2 (CSMD1), 8q21.3 (MMP16), 10q24.32-q24.33 (CNNM2/NT5C2). W tym samym roku zidentyfikowano loci charakterystyczne dla ludzi z krajów Wschodu (11p11.2, 8p12, 1q24.2). [12]

Badania GWAS pozwalają nie tylko określić punktowe mutacje w genomie, ale także próbują dać odpowiedź na pytanie o biologiczne mechanizmy choroby. Przykładem może być mikroRNA MIR137, które bierze udział w neurogenezie i dojrzewaniu neuronów. Jak się okazuje, większość znalezisk współdziała w neurorozwoju czy plastyczności neuronów. [8] Według badaczy mikroRNA może mieć kolosalne znaczenie w koordynacji ogromnej sieci białek, zwłaszcza chodzi tu o dwa mikroRNA regulujące receptor B1 GABA. Gen GABBR1 mieści się w obrębie genów głównego układu zgodności tkankowej, ostatnio okazał się być genem poddawanym największej metylacji i jest kluczowy w tworzeniu ścieżek sygnałowych w schizofrenii. Wg badań GWAS region MHC, na którym zlokalizowany jest GABBR1 posiada największą liczbę SNP. [11]

CNV (copy number variant), czyli zmienność liczby kopii fragmentów DNA to zaburzenie ilościowe wewnątrz chromosomu; czasami duplikacji lub delecji może ulec nawet kilka genów. Badania wykazały, że mikrodelecje występują częściej w schizofrenii zakłócając geny odpowiedzialne za procesy neurorozwojowe i plastyczność synaptyczną. [7] Od 2008 roku zbadano wiele CNV związanych z występowaniem schizofrenii. Wydaje się, że do istotych znalezisk należą loci: 1q21.1, 2p16.3, 3q29, 15q11.2, 15q13.3, 16p13.1, 22q11.2.[9] Sposród nich najważniejsza wydaje się być mikrodelecja 3q29. [10] Delecje wykazują większą penetrację niż duplikacje, podobnie jak większe CNV. Znaczna liczba CNV jest dziedzicznych, jednak nowo powstałe mutacje również odgrywają ważną rolę w schizofrenii. Są one odpowiedzialne na przykład za występowanie schizofrenii tylko u jednego z bliźniąt jednojajowych. [9] Badacze angielscy i amerykańscy przebadali 662 trójki proband-rodzice i stwierdzili, że mutacje de novo były znacznie częstsze niż w grupie kontrolnej $(5,1 \%$ vs $2,2 \%)$. Osiem z nowopowstałych CNV było zlokalizowanych na wspomnianych już loci: 3q29, 15q11.2, 15q13.3, 16p11.2. Zauważono także pojawienie się CNV związanych z zaburzeniami innymi niż schizofrenia np. delecja w regionie 1q21.1 (TAR - zespół małopłytkowości i aplazji kości promieniowej) czy duplikacja w regionie 7q11.23 (zespół Williamsa-Beurena). [13]

Badacze postanowili zbadać udział mutacji de novo w schizofrenii, określić białka wytwarzane przez zmutowane geny oraz ich rolę w mózgu na przestrzeni rozwoju człowieka. Ich ustalenia potwierdziły, że u podłoża schizofrenii leżą zaburzenia w płodowej korze przedczołowej. Ten region mózgu jest silnie połączony z innymi obszarami kory, zwojami podstawy, układem limbicznym. Dlatego tak ważny jest skoordynowany rozwój i regulacja przestrzenna, by utworzyć zintegrowaną sieć połączeń nerwowych. Ekspresja genów zmutowanych de novo ma swój wyraz także w innych obszarach mózgu, takich jak: płaty czołowe i skroniowe, hipokamp, ciało migdałowate, wzgórze. Geny ITGA3, LAMA2 odgrywają kluczową rolę w migracji neuronalnej, SLIT2 $i$ SLIT3 w przekazywaniu informacji przez aksony. CELSR2 bierze udział w transdukcji sygnałów i adhezji komórkowej, zaś ADCY9,CACNA1I, GLS, SLC18A2 w sygnalizacji neurotransmiterów i transmisji synaptycznej. I właśnie gen CACNA1I koduje specyficzny dla mózgu kanał wapniowy typu T, którego antagonistą jest np. klo zapina. Profile ekspresji genów CELSR2, HIVEP1, ITGA3, SERPINI1, SLIT2 były odmienne u neuronów otrzymanych z komórek macierzystych chorych na schizofrenię w porównaniu do grupy kontrolnej. Możliwość wielogenowego oddziaływania sugeruje fakt, że dziewięciu pacjentów spośród badanych miało mutację w więcej niż jednym genie. [14]

Drugą ważną grupą czynników etiologicznych są czynniki środowiskowe warunkujące pojawienie się choroby u osób predysponowanych genetycznie. W ostatnich 
latach schizofrenia zaczęła być postrzegana przez pryzmat hipotezy neurorozwojowej, według której niekorzystne czynniki prowadzą do nieprawidłowego rozwoju mózgu podczas okresu okołourodzeniowego. Niewątpliwie istotną przestrzenią wspólną dla kilku czynników środowiskowych jest stres. Biologiczną konsekwencją stresu jest dysregulacja osi podwzgórze-przysadkanadnercza i wzrost uwalniania dopaminy w prążkowiu. Ponadto maleje objętość hipokampa za względu na degenerację neuronów, zmniejsza się plastyczność synaps w korze przedczołowej. [15]

Hipoteza neurozwojowa znajduje odzwierciedlenie w badaniach ukazujących wpływ matczynego stresu na płód. Stres związany z trudnymi życiowymi doświadczeniami jak wojna, żałoba, niechciana ciąża, szczególnie szkodzi dziecku w I i II trymestrze ciąży, kiedy rozwój mózgu jest najbardziej podatny na uszkodzenia. Ponadto następuje wspomniana już dysregulacja osi podwzgórzeprzysadka-gonady i niekorzystny wpływ na funkcję łożyska. Płód narażony na czynniki stresowe ma większe ryzyko zachorowania na schizofrenię, depresję i zaburzenia lękowe. Głównie zmiany lokalizują się w hipokampie i ciele migdałowatym, gdzie następuje zwiększona ekspresja receptorów steroidowych oraz dla hormonu CRH. Na podstawie modeli zwierzęcych wykazano, że dysfunkcja tych obszarów mózgowych związana ze stresem w okresie prenatalnym jest przyczyną deficytów poznawczych, pamięci operacyjnej, pamięci przestrzennej, rozpoznawania nowych obiektów. [15]

W okresie płodowym i okołourodzeniowym nie tylko stres ma udowodniony wpływ na rozwój schizofrenii, ale także takie czynniki jak niedotlenienie, poród przedwczesny, zakażenia, krwawienia, cukrzyca w okresie ciąży, konflikt serologiczny. [16] Za wymienione powyżej zakażenia odpowiedzialne są przede wszystkim wirus grypy, odry, różyczki, VZV, polio, herpes czy Toxoplasma gondii. Inne źródła wskazują na kolejne powikłania położnicze będące czynnikami ryzyka schziforenii, są to: stan przedrzucawkowy, atonia macicy, nagłe cięcie cesarskie oraz nieprawidłowości u płodu: małogłowie, niska masa urodzeniowa, wrodzone malformacje. [15]

Jednym z czynników związanych ze stresem jest emigracja. Emigranci są dyskryminowani społecznie, doświadczają wykluczenia społecznego, co przyczynia się do powstania zaburzeń psychicznych. Jednak na przestrzeni lat wskazano na możliwość niedostosowania układu immunologicznego emigrantów do występujących na danym terenie wirusów neurotropowych czy pasożytów. Częstsze występowanie schizofrenii dotyczy pierwszego i drugiego pokolenia emigrantów, a także mniejszości narodowych. Sugerowano również nadrozpoznawalność schizofrenii u emigrantów z powodu mylenia objawów choroby z trudnościami językowymi. [15][16]
Bardzo ważnym aspektem pozostaje zamieszkiwanie na terenach o wysokim stopniu urbanizacji. Wiąże się to ze zwiększoną aktywnością ciała migdałowatego czy kory zakrętu przedniego. Ryzyko wystąpienia choroby jest 1,5-krotnie większe u osób żyjących w dużym mieście. Według badania Pedersena i Mortensena najbardziej niekorzystne jest zamieszkiwanie aglomeracji miejskich do 15 roku życia. [15][16]

Urazy głowy zdarzają się często osobom chorym na schizofrenię, które mają zaburzone funkcje poznawcze. Jednak z drugiej strony urazy głowy poprzez uszkodzenie mózgu, mogą być przyczyną rozwoju choroby. [16] Łagodne urazy głowy w dzieciństwie obniżają wiek wystąpienia pierwszych objawów u osób z silną predyspozycją genetyczną. Psychoza u takich osób pojawia się około 5 lat wcześniej. Mimo to większość urazów głowy u dzieci pozostaje bez konsekwencji. [17]

Kannabinole badane są pod kątem ich działania terapeutycznego w schizofrenii. Jednak wiele analiz pokazuje, że są też istotnym czynnikiem ryzyka wystąpienia choroby. Przede wszystkim używanie THC (delta-9tetrahydrokanabinolu) przez młodzież może doprowadzić do pojawienia się objawów schizofrenii we wczesnej dorosłości. Obserwacje te dotyczą zwłaszcza młodzieży z rodzin obciążonych chorobą czy narażonych na przemoc w dzieciństwie. [18][19] Efekt używania kannabinoli zależy też oczywiście od czasu używania, częstotliwości, dawki. Deficyty poznawcze mogą się wyrównywać dzięki abstynencji, natomiast inne nieprawidłowości (uwagi, pamięci operacyjnej, funkcji wykonawczych) bywają długotrwałe u osób, które rozpoczęły palenie marihuany przed 15 rokiem życia. Tak wczesne używanie THC uniemożliwia końcowe dojrzewanie mózgu poprzez zakłócanie wewnętrznego układu kannbinoidowego. [20]

\section{Podsumowanie}

Niniejszy artykuł stanowi przegląd tylko niektórych ważnych w etiologii schizofrenii czynników. Mimo rozwoju psychiatrii jako dyscypliny medycznej ta jednostka chorobowa wciąż pod pewnymi względami wydaje się zagadką, niewątpliwie jednak na wystąpienie choroby wpływają zarówno czynniki genetyczne jak i środowiskowe.

Wzajemne powiązania między poligenowym uwarunkowaniem choroby a wpływem czynników środowiskowych i społecznych za pewne będą w przyszłości wdzięcznym polem do badań nad etiologią i przebiegiem chorób z grupy schizofrenii.

\section{Conflict of interest}

The authors have declared no conflict of interest.

\section{References:}

1. Oniszczenko W., Dragan W.t. Genetyka zachowania w psychologii i psychiatrii. Wydawnictwo Naukowe SCHOLAR: 2008. 
2. Ritsner M.S. Handbook of Schizophrenia Spectrum Disorders. Volume 1. 2011.

3. Jarema M. Psychiatria. Podręcznik dla studentów medycyny. PZWL: 2011

4. Girard S.L., Dion P.A., Rouleau G.A. Schizophrenia Genetics: Putting All the Pieces Together; 2012.

5. Suchanecka A., Grzywacz A., Samochowiec J. Gen ANKK1 w psychiatrii, 2011

6. Sanders A.R. Genetics of Schizophrenia, 2014.

7. Hauser J.W. Co badania asocjacyjne całego genomu (GWAS) wniosły do psychiatrii?, 2013.

8. Bergen S.E., Petryshen T.L. Genome-wide association studiem (GWAS) of schizophrenia: does bigger lead to better results?, 2013.

9. Hosak L., Silhan P., Hosakowa J. Genomic copy number variations: A breakthrough in our knowledge on schizophrenia etiology?, 2012.

10. Kotlar A.V., Mercer K.B., Zwick M.E., Mulle J.G. New discoveries in schizophrenia genetics reveal neurobiological pathways: A review of recent findings, 2015

11. Gumerov V., Hegyi H. MicroRNA-derived network analysis of differentially methylated genes in schizophrenia, implicating GABA receptor B1 [GABBR1] and protein kinase B [AKT1], 2015.

12. Ripke S., Sanders A.R., Kendler K.S. Genome-wide association study identifies five new schizophrenia loci, 2011.

13. Kirov G., Pocklington A.J., Holmans P., Ivanov D., Ikeda M. De novo CNV analysis implicates specific abnormalities of postsynaptic signalling complexes in the pathogenesis of schizophrenia, 2012.

14. Gulsuner S., Walsh T., Watts A.C., Lee M.K., Thornton A.M. Spatial and Temporal Mapping of De Novo Mutations in Schizophrenia to a Fetal Prefrontal Cortical Network, 2013.
15. 15.Schmitt A., Malchow B., Hasan A., Fallkai P. The impact of environmental factors in severe psychiatric disorders, 2014.

16. Hauser J. Interakcja czynników genetycznych i środowiskowych w schizofrenii, 2007.

17. AbdelMalik P., Husted J., Chow E.W.C., Bassett A.S. Childhood Head Injury and Expression of Schizophrenia in Multiply Affected Families, 2003.

18. Renard J., Rosen L.G., Loureiro M., De Oliveira C., Schmid S., Rushlow W.J. et al: Adolescent Cannabinoid Exposure Induces a Persistent Sub-Cortical Hyper-Dopaminergic State and Associated Molecular Adaptations in the Prefrontal Cortex, 2016.

19. Manseau M.W., Goff D.C. Cannabinoids and Schizophrenia: Risks and Therapeutic Potential, 2015.

20. Dervaux A., Krebs M.O., Laqueille X. Cannabis-induced cognitive and psychiatric disorders, 2015

\section{Correspondence address}

Ewelina Dziwota

II Klinika Psychiatrii i Rehabilitacji Psychiatrycznej

Ul. Głuska 1, 20-439 Lublin

Email: dziwota.e@gmail.com

Otrzymano: 14.06 .2016

Zrecenzowano: 04.08.2016, 18.09.2016

Przyjęto do druku: 01.10.2016 